\title{
Evaluation of Host Resistance and Soil Fumigation for the Management of Black Root Rot of Tobacco in Ontario
}

\author{
H. M. Haji, Canadian Tobacco Research Foundation, P.O. Box 186, Delhi, Ontario N4B2W9, Canada; and \\ J. E. Brandle, Agriculture and Agri-food Canada, P.O. Box 186, Delhi, Ontario N4B2W9, Canada
}

\begin{abstract}
Haji, H. M., and Brandle, J. E. 2001. Evaluation of host resistance and soil fumigation for the management of black root rot of tobacco in Ontario. Plant Dis. 85:1145-1148.

Black root rot of tobacco, caused by the soilborne fungus Thielaviopsis basicola, is a serious problem in many tobacco (Nicotiana tabacum L.)-growing regions of the world. In Ontario, the disease is favored by cool, wet soil conditions and heavy textured or poorly drained soils. Yield loss can be severe under these conditions and fumigants containing chloropicrin are used extensively for controlling the disease. Usually, fumigants control the disease reasonably well, but they are costly and could cause a negative environmental impact. A 2-year study was conducted to evaluate the performance of resistant (AC Gayed) and moderately susceptible (Delgold) tobacco cultivars and soil fumigation to black root rot. T. basicola reduced yield of the susceptible Delgold cultivar. The interaction between genotype and fumigation was significant for most traits examined, indicating that the two genotypes responded differently. Orthogonal comparisons indicate that yield from nonfumigated AC Gayed was higher than that of nonfumigated Delgold. Yield of nonfumigated AC Gayed was also not significantly different from the yield of AC Gayed treated either with Vorlex Plus (1,3-dichloropropene+methyl isothiocyanate) or with Vorlex Plus CP (1,3-dichloropropene+methyl isothiocyanate+chloropicrin). In contrast, the yield of nonfumigated Delgold was lower than Delgold treated with Vorlex Plus CP.
\end{abstract}

Black root rot, caused by Thielaviopsis basicola (Berk. \& Broome) Ferraris, is a common soilborne fungus found in many major tobacco (Nicotiana tabacum L.)growing regions of the world. The disease, characterized by black lesions on the roots and hypocotyl, causes stunting, late maturation, and uneven stands, all of which reduce yield and quality of tobacco (15). In Canada, crop loss in any given year is usually low, around $0.08 \%$; however, the cost of control using fumigants is high, amounting to $\$ 2.3$ million Canadian per year. At high infestation levels, plant leaves turn pale green to yellow and stunting is severe (11). The level of damage from the disease is generally associated with several soil and environment factors. Conditions such as heavy textured or poorly drained soils and cool, wet soils favor disease development and spread. Soil temperatures affect black root rot development by retarding growth of the host relative to that of the fungus $(8,10,12)$. Temperatures between 17 and $23^{\circ} \mathrm{C}$ are considered optimal for disease development (2). Disease severity is greatly reduced at $26^{\circ} \mathrm{C}$ and is negligible at soil temperatures above $30^{\circ} \mathrm{C}(9)$. Soil $\mathrm{pH}$

Corresponding author: H. M. Haji

E-mail: hhaji@ ontarioflue-cured.com

Accepted for publication 22 June 2001.

Publication no. D-2001-0824-01R

(C) 2001 The American Phytopathological Society affects yield losses due to black root rot. The disease rarely occurs when soil $\mathrm{pH}$ is below 5.4 and is most severe above $\mathrm{pH} 5.6$ (4). Use of cultivars with low levels of partial resistance and continuous planting of tobacco or other susceptible crops can increase the severity of the disease $(1,11,16,17)$.

Several soil fumigants are widely used to control black root rot (20). Fumigants containing chloropicrin (Telone C-17R and Vorlex Plus CP) are more effective than others (6). Fumigants are injected into the soil (15 cm deep) 3 weeks before transplanting. Generally, the effectiveness of fumigation depends on the fumigant used and the environmental conditions present at the time of fumigation. Fumigants are least effective in cool, wet soil because they fail to disperse adequately through the soil (5). These same conditions favor development of severe disease early in the growing season by $T$. basicola (11).

Host plant resistance is among the primary means of controlling black root rot on flue-cured tobacco in Ontario. The first flue-cured cultivar resistant to black root rot was released in 1949 (10). Since then, several other resistant cultivars have been registered. About $95 \%$ of the flue-cured tobacco cultivars grown in Ontario have low to moderate levels of resistance derived from $N$. tabacum sources. The remaining 5\% have a very high level of monogenic resistance derived from $N$. debneyi. Despite the availability of resistant cultivars with monogenic sources of resistance that are well adapted to the growing conditions of Ontario, information on the performance of these cultivars with and without fumigation treatments is still lacking. This study was undertaken to evaluate host plant resistance and chloropicrin-containing fumigants.

\section{MATERIALS AND METHODS}

Field trials were conducted in 1996 and 1997 at Paloot's farm. The soil type is Granby sandy loam consisting of $84 \%$ sand, $6.5 \%$ clay, and $9.5 \%$ silt. The farm is located $5 \mathrm{~km}$ east of the Southern Crop Protection and Food Research Centre, Delhi (latitude $42^{\circ} 52^{\prime}$, longitude $80^{\circ} 33^{\prime}$ ), Ontario. This site has been continuously cropped to tobacco for the last 45 years and has a long history of severe and uniform black root rot. The fumigation treatments were 1,3 dichloropropene+methylisothiocyante (Vorlex Plus) at 56.7 liters ha ${ }^{-1}, 1,3$ dichloropropene + methylisothiocyante + chloropicrin (Vorlex Plus CP) at 66.7 liters $\mathrm{ha}^{-1}$, and a nonfumigated control. All fumigation treatments were applied on 4 May 1996 and 5 May 1997 at a depth of 15 $\mathrm{cm}$ by chisel placement, using a single-row gravity flow applicator. The fumigant was sealed immediately after the application by ridging the row by means of two disks attached to the tractor. The seedlings were raised in a greenhouse with a uniform muck layer $7.5 \mathrm{~cm}$ thick and with a seeding rate of approximately 110 to 120 seed per $930 \mathrm{~cm}^{2}$. Nine-week-old seedlings of the susceptible cv. Delgold and resistant cv. AC Gayed were transplanted on 4 June 1996 and 5 June 1997 into plots of three rows, $23 \mathrm{~m}$ long. The rows were spaced $107 \mathrm{~cm}$ apart, containing 38 plants with 61 $\mathrm{cm}$ between plants, resulting in a planting density of 15,441 plants $\mathrm{ha}^{-1}$. Production practices were those normally employed for flue-cured tobacco grown in southwestern Ontario (20).

In both years of the experiment, T. basicola and nematode populations were evaluated. Soil was randomly sampled twice (prior to fumigation and midseason) for nematode counts and four times (prior to fumigation in the first week of May and three times during the growing season in the first weeks of June, July, and August) for T. basicola populations. Each soil sample was a composite of six 3-cm-diameter soil cores taken to a depth of $20 \mathrm{~cm}$. $T$. basicola populations in each treatment were estimated using the technique de- 
scribed by Mayer et al. (17) and Specht and Griffin (22), in which $10 \mathrm{ml}$ of soil suspension $(1: 100$, wt/wt) in deionized water was pipetted into $300 \mathrm{ml}$ of a malten medium containing $50 \mathrm{ml}$ of canned carrot juice, $18 \mathrm{~g}$ of agar, $950 \mathrm{ml}$ of deionized water, and the antibiotics described by Specht and Griffin (22). The agar-soil suspension was mixed thoroughly on a magnetic stir plate, divided equally into 10 plastic petri dishes, and incubated for 14 days at room temperature $\left(22\right.$ to $\left.25^{\circ} \mathrm{C}\right)$ in

Table 1. Individual analyses of variance of Thielaviopsis basicola population $(\log [X+1]$ transformed) for 1996 and 1997 trials conducted at Paloot's farm in southwestern Ontario

\begin{tabular}{|c|c|c|c|c|c|}
\hline \multirow[b]{3}{*}{ Source of variation } & \multirow[b]{3}{*}{ df } & \multicolumn{4}{|c|}{ Mean square $^{\mathrm{z}}$} \\
\hline & & \multicolumn{2}{|c|}{1996} & \multicolumn{2}{|c|}{1997} \\
\hline & & May 4 & June 4 & May 5 & June 5 \\
\hline$\overline{R e p}$ & 3 & 0.054 & $0.164 *$ & $0.263 * *$ & 0.029 \\
\hline Treatment & 5 & 0.038 & $0.188^{* * *}$ & 0.058 & $1.682 * *$ \\
\hline Genotype & 1 & 0.000 & 0.000 & 0.003 & 0.233 \\
\hline Fumigation & 2 & 0.043 & $0.469 * *$ & 0.111 & $3.443^{* *}$ \\
\hline Genotype $\times$ fumigation & 2 & 0.053 & 0.002 & 0.034 & $0.646 *$ \\
\hline Error & 15 & 0.056 & 0.031 & 0.046 & 0.161 \\
\hline
\end{tabular}

${ }^{\mathrm{z}}$ May dates are prior to fumigation and June dates are postfumigation; $*$ and $* *$ significant at $P<$ 0.05 and $P<0.01$ respectively.

Table 2. Thielaviopsis basicola population $(\log [X+1]$ transformed) prior to and after fumigation in 1996 and 1997 at Paloot's farm in southwestern Ontario

\begin{tabular}{lccccc}
\hline & \multicolumn{4}{c}{ Mean T. basicola population ${ }^{\mathbf{z}}$} \\
\cline { 2 - 3 } \cline { 2 - 3 } Treatments & May 4 & June 4 & & \multicolumn{2}{c}{$\mathbf{1 9 9 7}$} \\
\cline { 2 - 3 } \cline { 5 - 6 } Delgold-NF $\mathbf{5}$ & June 5 \\
Gayed-NF & $2.00 \mathrm{a}$ & $1.82 \mathrm{a}$ & & $1.79 \mathrm{a}$ & $1.26 \mathrm{ab}$ \\
Delgold + VO & $1.92 \mathrm{a}$ & $1.79 \mathrm{a}$ & & $1.97 \mathrm{a}$ & $1.68 \mathrm{a}$ \\
Gayed + VO & $1.73 \mathrm{a}$ & $1.73 \mathrm{a}$ & & $1.72 \mathrm{a}$ & $0.69 \mathrm{bc}$ \\
Delgold + VO + CP & $1.91 \mathrm{a}$ & $1.75 \mathrm{a}$ & & $1.67 \mathrm{a}$ & $0.00 \mathrm{~d}$ \\
Gayed + VO + CP & $1.91 \mathrm{a}$ & $1.35 \mathrm{~b}$ & & $1.94 \mathrm{a}$ & $0.49 \mathrm{~cd}$ \\
\hline
\end{tabular}

${ }^{\mathrm{z}}$ May dates are prior to fumigation and June dates are postfumigation. Different letters in the same column indicate statistical differences, $(P=0.05)$ according to the least significant difference test.

the dark. Nematode populations were estimated using the Baermann pan method (23).

Data were recorded on yield (leaf weight), grade index, days to flowering, topping height, and leaf area. Leaves were harvested over a 5-week period. Two to three ripe leaves were harvested every 4 to 7 days. The leaves were flue-cured and weighed to determine yield per hectare and were graded according to the Ontario Farm Products Grades and Sales Act (19) to determine the grade index in cents per kilogram on the average market price. Plots were topped when $50 \%$ of the plants had three open florets. Topping height of four randomly selected plants was measured from the ground level to the tip of the stem. Length and width of the eighth leaf was measured in four randomly selected plants to calculate the leaf area. To obtain the best estimate, the leaf area measured was multiplied by 0.675 .

Two cultivars and three fumigation treatments were evaluated in a factorial randomized complete block design with four replications. T. basicola population count were transformed by $\log (X+1)$ prior to analysis. The analysis of variance procedure described by Comstock and Moll (3) was used to test the significance of year, genotype, fumigation, and first and second order interactions. The year effect was assumed to be random, whereas genotype effects and fumigation effects were considered fixed. The significance of interaction terms were tested

Table 3. Combined analyses of variance of yield and agronomic traits for 1996 and 1997 trials conducted at Paloot's farm in southwestern Ontario

\begin{tabular}{|c|c|c|c|c|c|c|}
\hline \multirow[b]{2}{*}{ Source of variation } & \multirow[b]{2}{*}{ df } & \multicolumn{5}{|c|}{ Mean squares ${ }^{y}$} \\
\hline & & Yield (kg/ha) & Grade index (c/kg) & Days to flower & Topping height & Leaf area (8th leaf) \\
\hline Year & 1 & $1,388,560 * *$ & $6,097.5^{* *}$ & $50.02 * *$ & $1,507.41 * *$ & $2,185,843 * *$ \\
\hline Rep (year) & 6 & $58,210^{*}$ & 388.6 & $4.83^{*}$ & $64.54 * *$ & 27,915 \\
\hline Treatment & 5 & $545,029 * *$ & 2,328 & $90.37 * *$ & $60.98 * *$ & $136,456^{* *}$ \\
\hline Genotype & 1 & $2,325,840 * *$ & 682.5 & $275^{* *}$ & $138.8 * *$ & $483,034 * *$ \\
\hline Fumigant & 2 & 17,418 & 187.5 & $70^{* *}$ & 1.29 & $4,505^{*}$ \\
\hline Year $\times$ genotype & 1 & $99,554 *$ & 93.5 & 4.69 & 3.19 & 56,183 \\
\hline Year $\times$ fumigant & 2 & 27,477 & 588.6 & 1.89 & 14.18 & 27,682 \\
\hline Genotype $\times$ fumigant & 2 & $182,234 * *$ & 53.1 & $17.77 * *$ & $81.76^{*}$ & $95,116 * *$ \\
\hline Year $\times$ Genotype $\times$ fumigant & 2 & 19,005 & 516.6 & $6.44 *$ & 4.76 & 7,589 \\
\hline Error & 30 & $2,365,754$ & 233.9 & 1.44 & 12.41 & 13,892 \\
\hline $\mathrm{CV} \%{ }^{2}$ & $\ldots$ & 5.59 & 3.79 & 1.75 & 3.67 & 9.8 \\
\hline
\end{tabular}

y $*$ and $* *$ significant at $P<0.05$ and $P<0.01$, respectively.

${ }^{\mathrm{z}} \mathrm{CV} \%=$ coefficient of variation.

Table 4. Minimum and maximum temperatures and rainfall during the 1996 and 1997 growing seasons at the Southern Crop Protection and Food Research Centre-Delhi (Ontario, Canada)

\begin{tabular}{|c|c|c|c|c|c|c|c|c|}
\hline \multirow[b]{3}{*}{ Month } & \multicolumn{6}{|c|}{ Temperature $\left({ }^{\circ} \mathbf{C}\right)$} & & \\
\hline & \multicolumn{2}{|c|}{ Maximum } & \multicolumn{2}{|c|}{ Minimum } & \multicolumn{2}{|c|}{ Mean } & \multicolumn{2}{|c|}{ Rainfall (mm) } \\
\hline & 1996 & 1997 & 1996 & 1997 & 1996 & 1997 & 1996 & 1997 \\
\hline April & 9.8 & 11.8 & 0.6 & -0.7 & 5.2 & 5.6 & 149 & 36 \\
\hline May & 17.7 & 15.2 & 4.9 & 4.0 & 11.4 & 9.6 & 153 & 158 \\
\hline June & 24.8 & 25.8 & 13.7 & 12.9 & 19.3 & 19.4 & 147 & 103 \\
\hline July & 26.2 & 26.6 & 13.6 & 14.2 & 19.9 & 20.4 & 85 & 72 \\
\hline August & 27.7 & 24.0 & 13.7 & 12.1 & 20.7 & 18.1 & 33 & 77 \\
\hline September & 21.5 & 21.3 & 10.9 & 9.2 & 16.2 & 15.3 & 221 & 76 \\
\hline Average & 21.3 & 20.8 & 9.6 & 8.6 & 15.5 & 14.7 & & $\ldots$ \\
\hline Total & $\ldots$ & $\ldots$ & $\ldots$ & $\ldots$ & $\ldots$ & $\ldots$ & 788 & 522 \\
\hline
\end{tabular}


using a procedure outlined by McIntosh (13). Data were analysed using the general linear models procedure and Duncan's multiple range test (SAS Institute, Cary, NC). Contrasts calculated from the treatment effects of the analysis of variance were used to compare (i) Delgold and AC Gayed under zero fumigation, (ii) Delgold nonfumigated to fumigated, and (iii) AC Gayed nonfumigated to fumigated.

\section{RESULTS AND DISCUSSION}

T. basicola populations. Individual analyses of variance prior to fumigation of T. basicola population count in 1996 and
1997 (Table 1) suggest no differences in the main and interaction effects. However, the postfumigation count was significant among treatment means in both years. The postfumigation differences in the treatment effect were mainly attributed to effects contributed by fumigation. The genotypefumigation interaction was significant in 1997 postfumigation. In 1996 and 1997, postfumigation counts of $T$. basicola were significantly lower on Vorlex Plus CP fumigated treatments (Table 2). However, in contrast to the results of 1996 postfumigation counts, treatments with Vorlex Plus fumigation in 1997 significantly reduced the numbers of $T$. basicola propagules.

Table 5. Contrasts between various treatment effects for yield, days to flowering, topping height, and leaf area

\begin{tabular}{lcccc}
\hline & \multicolumn{4}{c}{ Mean squares $^{\mathbf{y}}$} \\
\cline { 2 - 5 } Contrast $^{\mathbf{z}}$ & $\begin{array}{c}\text { Yield } \\
\mathbf{( k g / h a )}\end{array}$ & $\begin{array}{c}\text { Days to } \\
\text { flower }\end{array}$ & $\begin{array}{c}\text { Topping } \\
\text { height }\end{array}$ & $\begin{array}{c}\text { Leaf area } \\
(8 \text { th leaf) }\end{array}$ \\
\hline D versus G & $1,067,605^{* *}$ & $156.25^{* *}$ & 0.25 & $53,282.5^{*}$ \\
D versus D + Vorlex Plus & 3,721 & $18.06^{* *}$ & $55.02^{*}$ & $85,042.22^{*}$ \\
D versus D + Vorlex Plus CP & $196,249^{* *}$ & $150.6^{* *}$ & 0.01 & $2,120.6$ \\
G versus G + Vorlex Plus & 13,398 & $10.56^{*}$ & $85.51^{* *}$ & $55,142.78^{*}$ \\
G versus G + Vorlex Plus CP & 36,864 & $20.25^{* *}$ & 4.7 & 954.96 \\
\hline
\end{tabular}

$\mathrm{y} *$ and $* *$ significant at $P<0.05$ and $P<0.01$, respectively.

${ }^{\mathrm{z}} \mathrm{D}=$ Delgold, $\mathrm{G}=$ AC Gayed.

Similar results were reported by Gayed (6). He found that Vorlex at a rate of 23 liters $\mathrm{ha}^{-1}$ reduced black root rot severity in 1 year out of 2 years of testing. Similarly, Telone $\mathrm{C}$ at a rate of 12 liters $\mathrm{ha}^{-1}$ reduced black root rot severity in 1975 , but 15 liters $\mathrm{ha}^{-1}$ in 1968 was not effective. Also, chloropicrin at 5 liters $\mathrm{ha}^{-1}$ neither stimulated tobacco growth nor reduced disease lesions in 1 year out of six seasons of testing. Gayed concluded that the failure of chloropicrin and other fumigants to increase tobacco growth and reduce black root rot severity in 1969 was attributed to rainfall in April and May, consisting of about 2.7 in. during the week before and 1.9 in. during the week after fumigation. Soil temperature is also known to influence the effectiveness of soil fumigants on soil organisms $(7,14)$ and the severity of black root rot of tobacco $(9,11)$.

The error values for the late-season $T$. basicola population counts were too high in both years to account for the actual differences among treatments. Therefore, the discussion is confined to dates prior to and the first count after fumigation.

Yield and agronomic traits. Significant differences in yield, grade index, days to flowering, topping height, and leaf area were present between the 2 years of testing
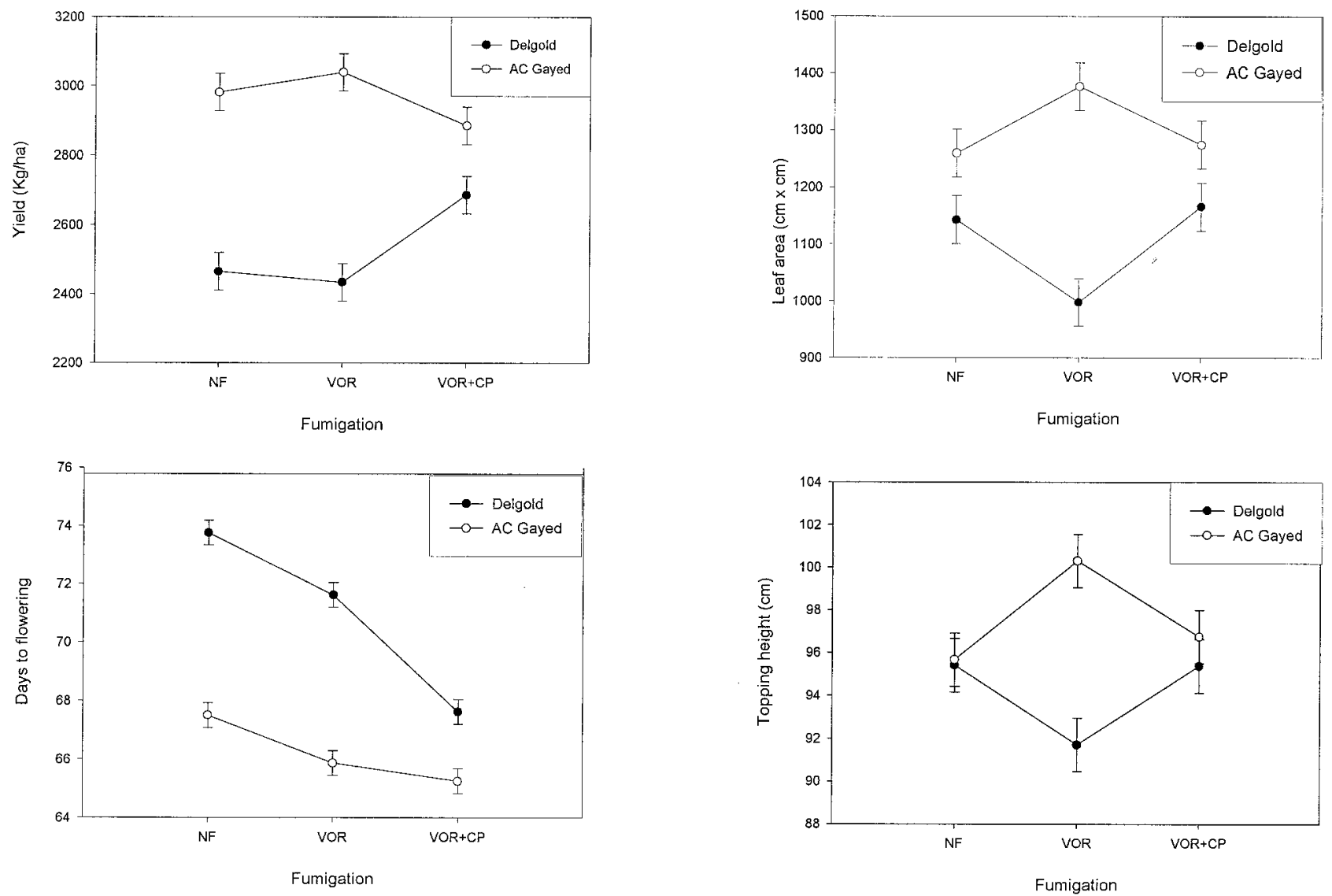

Fig. 1. Yield, leaf area, days to flowering, and topping height of a susceptible cultivar (Delgold) and a resistant cultivar (AC Gayed) to black root rot under different fumigation conditions at Paloot's farm in 1996 and 1997. NF = nonfumigated, VOR = fumigated with Vorlex only, VOR + CP $=$ fumigated with Vorlex and Chlorpicrin. Vertical bars indicate standard errors. 
(Table 3). Warm weather conditions early in the season and above-average precipitation during the 1996 growing season may have contributed to early crop establishment and faster crop growth and development (Table 4).

The difference among treatments and between the genotypic main effect were highly significant for all characters except the grade index (Table 3). The difference among the fumigation main effect was only significant for days to flowering and leaf area. The first order interaction effect of genotype-year was significant for yield, but the genotype-fumigation effect was significant for most of the traits, thus suggesting that the two genotypes reacted differently to the fumigation treatments. Orthogonal contrast (Table 5) showed that yield of nonfumigated AC Gayed was significantly higher than that of nonfumigated Delgold. Yield of nonfumigated Delgold was not different from the yield of Delgold treated with Vorlex Plus, but was significantly lower than the yield of Delgold treated with Vorlex Plus Chloropicrin (Table 5). This suggests that the nematode effect was not severe enough to cause differences in yield and quality. Root-lesion nematode counts ranged from 60 to 140 $\mathrm{kg}^{-1}$ of soil for 1996 and from 60 to $85 \mathrm{~kg}^{-}$ 1 soil for 1997 . These figures are considered too low to cause any appreciable damage to tobacco roots. Nematode economic threshold for tobacco is $1,100 \mathrm{~kg}^{-1}$ soil (18). Yield of nonfumigated AC Gayed was not different from the yield of AC Gayed treated either with Vorlex Plus or with Vorlex Plus CP. This result is in agreement with the results reported by Shew and Shoemaker (21). They found that yield between the fumigated and nonfumigated treatments was similar for cultivars with high level of resistance to $T$. basicola disease. In contrast, however, there was significant yield increase in the fumigated treatment of the susceptible cultivar.

Fumigation with Vorlex Plus and Vorlex Plus CP had no effect on the yield and leaf area of AC Gayed (Fig. 1A and B). The fumigation treatments decreased the number of days to flowering for both cultivars. In contrast to AC Gayed, topping height of Delgold fumigated with Vorlex Plus was significantly reduced (Fig. 1C and D). At present, almost $95 \%$ of the tobacco cultivars grown in Ontario have a moderate level of resistance controlled by a group of recessive genes derived from $N$. tabacum sources. However, AC Gayed falls into the first category of black root resistance described by Clayton (2), also know as immunity. The immunity to black root rot in these cultivars is controlled by a single dominant gene.

Results in this study suggests that $T . b a$ sicola-resistant cultivars can be used to manage black root rot grown in Ontario without the use of chloropicrin as a soil fumigant. However, the application of Vorlex Plus could reduce black root rot population, depending on soil conditions.

\section{LITERATURE CITED}

1. Anderson, T. R., and Welacky, T. W. 1988. Populations of Thielaviopsis basicola in burley tobacco field soils and the relationship between soil inoculum concentration and severity of disease on tobacco and soybean seedlings. Can. J. Plant Pathol. 10:246-251.

2. Clayton, E. E. 1969. The study of resistance to the black root rot disease of tobacco. Tob. Sci. 13: 30-37.

3. Comstock R. E., and Moll, R. H. 1963. Genotype-environment interactions. Pages 1164196 in Statistical genetics and plant breeding. NRC-NAS No. 982.

4. Doran, W. L. 1931. Increasing soil acidity as a means of controlling black root rot of tobacco. Pages 118-146 in: Mass. Agric. Exp. Stn. Bull. 276.

5. Gayed, S. K. 1967. Effect of fumigation on black root rot disease of tobacco. Lighter 37:10-16.

6. Gayed, S. K. 1977. The effect of chloropicrin and other soil fumigants on Theilaviopsis root rot of tobacco in Ontario. Tob. Sci. 21:25-28.

7. Goring, C. A. 1962. Theory and principles of soil fumigation. Adv. Pest Control Res. 5:47-84.

8. Hsi, D. C. H. 1977. Effect of temperature and precipitation on Valencia peanut production and hull discoloration. New Mexico, 19481976. N.M. Agric. Exp. Stn. Res. Rep. 353.
9. Johnson, I., and Hartman, R. 1919. Influence of soil environment on root rot of tobacco. J. Agric. Res. 17:41-86.

10. Lloyd, A. B., and Lockwood, J. L. 1963. Effect of soil temperature, host variety, and fungus strain on Thielaviopsis root rot of peas. Phytopathology 53:329-331

11. Lucas, G. B. 1975. Disease of Tobacco. Biological Consulting Associates, Raleigh, N.C.

12. Mauk, P. A., and Hine, R. B. 1988. Infection, colonization of Gossypium hirsutum and G.barbadense, and development of black root rot caused by Thielaviopsis basicola. Phytopathology 78:1662-1667.

13. McIntosh, M. S. 1983. Analysis of combined experiments. Agron. J. 75:153-155.

14. McKenry, M. V., and Thomason, I. J. 1971. Effect of soil porosity, moisture, and temperature on diffusion of 1,3-dichloropropene nematocides. (Abstr.) Phytopathology 61:903.

15. Meyer, J. R., and Shew, H. D. 1991. Development of black root rot on burley tobacco as influenced by inoculum density of Thielaviopsis basicola, host resistance, and soil chemistry. Plant Dis. 75:601-605.

16. Meyer, J. R., and Shew, H. D. 1991b. Soils suppressive to black root rot of burley tobacco caused by Thielaviopsis basicola. Phytopathology 81:946-954.

17. Meyer, J. R, Shew, H. D., and Shoemaker, P. B. 1989. Populations of Thielaviopsis basicola and the occurrence of black root rot on burley tobacco in western North Carolina. Plant Dis. 73:239-242.

18. Olthof, Th. H. A., Marks, C. F., and Elliot, J. M. 1973. Relationship between populations densities of Pratylenchus penetrans and crop losses in flue-cured tobacco in Ontario. J. Nematol. 5:158-162.

19. Ontario Farm Product Grades and Sales Act and regulations respecting flue-cured tobacco. 1965. P10-25. Toronto, Ontario.

20. Ontario Ministry of Agriculture, Food, and Rural Affairs. 1995. Tobacco Page 23 in: Production Recommendations. Publication 298. Guelph, Ontario, Canada.

21. Shew, H. D., and Shoemaker, P. B. 1993. Effects of host resistance and soil fumigation on Thielaviopsis basicola and development of black root rot on burley tobacco. Plant Dis. 77:1035-1039.

22. Specht, L. P., and Griffin, G. J. 1985. A selective medium for enumerating populations of Thielaviopsis basicola in tobacco field soils. Can. J. Plant Pathol. 7:438-441.

23. Townshend, J. L. 1963. A modification and evaluation of the apparatus for the oostenbrink direct cottonwool filter extraction method. Nematologica 9:106-110. 